\title{
A Study on Agreement Analysis in Job Selection Decisions With Respect To Locus of Control
}

\author{
Mehmet Nuri Inel \\ Assistant Professor, Marmara University \\ Faculty of Business Administration, Istanbul /Turkey \\ E-mail: mninel@marmara.edu.tr
}

Received: February 15, 2017 Accepted: March 1, 2017

doi:10.5296/ber.v7i1.10704 URL: https://doi.org/10.5296/ber.v7i1.10704

\begin{abstract}
The importance of job selection decisions increases day by day. The aim of this study is to evaluate agreement coefficients by measuring the effect of locus of control (LOC) orientation and to analyze agreement in job selection decisions with respect to locus of control. In order to test the propositions, a field survey using questionnaires was conducted in a sample of 200 . Results indicated that there was an agreement between internals and externals.
\end{abstract}

Keywords: Coefficients of Agreement, Job Selection Decisions, Locus of Control

\section{Introduction}

The importance of job selection decisions increases day by day. Because these decisions affect future career of the individual. The construct of this study is to compare agreement coefficients. Especially, this study compares agreement coefficient by measuring agreement of people that have different locus of control orientations that are internals and externals about job selection decisions. An empirical research was conducted in order to measure locus of control orientations and job selection decisions. All participants were Bachelor students in the Faculty of Business Administration of Marmara University, Turkey. It was calculated agreement coefficient with respect to results of empirical research.

The aim of this study is evaluate Krippendorff's kappa, Cohen's alpha and percentage agreement in job selection decision with respect to difference of locus of control.

The study has two main section. The first section includes literature review about coefficients of agreement, locus of control and job selection decisions. The second section includes methodology, findings, conclusion and recommendations. 


\section{Coefficients of Agreement}

It is compared between percent agreement, Cohen's kappa and Krippendorf's Alpha in this paper. It is presented general definition and literature review in this section.

It is noticed that agreement and reliability are named in same coefficient names in literature. But Krippendorff clarified relation between agreement and reliability (Krippendorf, 2004 a). There was a study about agreement and information too (Krippendorff, 2011a). Krippendorff's alpha is generally used for content analysis (Gwet, 2016).

The general form of alpha is:

$$
\alpha=1-\frac{D_{o}}{D_{e}}
$$

Do: observed disagreement

De: expected disagreement

If observed disagreement is absent, Do is zero and $\alpha$ is one. The study, that includes this general form, expressed family of alpha agreement measures (Krippendorff, 2004 b).

Krippendorff's alpha is defined as a reliability coefficient that is developed to measure agreement among raters. Computation of Krippendorff's alpha for different scale is expressed in "Computing Krippendorff's Alpha-Reliability" by Krippendorff. (Kirppendorff 2011b). It is also expressed that applying situations of alpha at the same study.

It is understood that is used Krippendorff's alpha for ratio measurement for computing of agreement.

Krippendorff's alpha is both more flexible than kappa, ICC (intra-class correlation) and can be generalized for different variable types (ratio, nominal etc.) (Hallgren, 2012). It can be assumed as a superiority for alpha.

The other agreement coefficient that was used in this paper are percent agreement and Cohen's kappa. Shortly, percent agreement is calculated with number of agreements and number of decisions. It is proportion of units. Percentage formula is, as a percentage: (Taylor, 2007; Araujo and Born, 1985)

$$
\text { Percentage Agreement }=\frac{\text { Agreements }}{\text { Agreements }+ \text { Disagreements }}
$$

Cohen's kappa is an agreement measure. It is asserted by Jacob Cohen in 1960, Kappa is one of the most known agreement coefficient. Cohen used the same conceptual formula of Scott's $\pi$ (Scott, 1955). Cohen' kappa also was criticized about characteristics. General formula of Cohen's kappa is presented for nominal scale: (Cohen, 1960; Lombard et al. 2002).

$$
\kappa=\frac{p_{o}-p_{c}}{1-p_{c}}
$$


Table 1 shows that some qualities of agreement coefficients (index), using this paper (Taylor, 2007).

Table 1. Qualities of agreement coefficients

\begin{tabular}{|c|c|c|c|c|}
\hline Index (Coefficient) & Multiple Surveyors & Metric & Change Agreement & Range Expressed \\
\hline Percentage Agreement & No & Nominal & N & $0-+1$ \\
\hline Cohen's Kappa & Yes & Nominal & Y & $-1-+1$ \\
\hline Krippendorff's Alpha & Yes & $\begin{array}{c}\text { Nominal, Ordinal, } \\
\text { Interval, Ratio }\end{array}$ & Y & $-1-+1$ \\
\hline
\end{tabular}

(Taylor, 2007)

There are studies that using these coefficient together for comparing or evaluating in literature. Most studies have used agreement coefficients for content analysis and reliability (Gwet, 2016; Hayes and Krippendorff, 2007; Lombard et al., 2002; Banerjee et al., 1999; Ato et al.. 2011; Taylor, 2007).

There are also studies that are compared with Cohen's kappa and different agreement coefficients. One of these is Warrens' study that was compared between Kappa and Gini's agreement coefficients (Warrens, 2013). Another study proposed fuzzy version of Cohen's kappa (Kirilenko and Stepchenkova, 2016).

It is not easy to calculate for three coefficients. But there is a web based program is called ReCal that computes these three agreement coefficients (Freelon, 2010). Data that were collected form survey was entered to this program and analyzed. It was used ReCal for analysis of kappa, alpha and percent agreement in this paper.

\section{Locus of Control}

Locus of control was proposed first by Julian Rotter in 1966. Locus of control is about one's values, past experiences, belief etc. Locus of control was classified two main parts. One of them is labeled "internal" the other is labeled "external" (Rotter, 1990; Gangai et al., 2016). Dağ has analyzed reliability and validity of Rotter's locus of control scale (Dağ, 1991).

Some of studies, in the literature, which related with locus of control and job satisfaction showed that locus of control is an important issue for job (Gangai et al., 2016; Akkaya and Akyol, 2016). Ahn investigated how a worker's locus of control affects job-to-job and job-to-non employment turnover (Ahn, 2015). Silvester et al investigated that locus of control in selection interview (Silvester et al. 2002).

There are also studies which related with locus of control and job seeking locus of control and career in decision in the literature (McGee 2015; Caliendo et al., 2010; Hooft and Crossley, 2008; Sahin et al., 2015; Öztemel, 2012).

\section{Job Selection Decisions and Motivators}

Job selection decisions are important for people. Because, choosing the right job is a strategic 
decision for personal success and happiness. There are many factors that affect job decision selection.

Aycan and Fikret-Paşa investigated job selection criteria and revealed the most motivating factors in job selection (Aycan and Fikret-Pasa, 2003). Bacanlı investigated career decision-making difficulties (Bacanl1, 2012).

There are many studies about job selection decisions in the literature (Hareli et al. 2008; Chan and Ho, 2000). Mustapha and Hassan presented perception of accounting students about job selection (Mustapha and Hassan, 2012). One of studies examined relationship between family status, job attribute preferences, welfare states, employment, work, family responsibilities (Corrigall, 2008). Another study is about social influences and job choice decisions (Kulkarni and Nithyanand, 2013). Bretz and Judge presented the role of human resource systems in job choice decision (Bretz and Judge 1992).

Keller et al presented objectives hierarchy for MBA students about choosing a new job after education (Keller et al., 2009).

\section{Methodology}

\subsection{Sample and Data Collection}

This study will attempt to answer the main two research questions: How much agreement is there between students having external and internal locus of control about job choice decisions? And what is the difference between coefficients of agreement on this issue? Before to answer these questions the locus of control oriented and job selection decisions were measured.

Data were collected from a sample of undergraduate students at Marmara University, Faculty of Business Administration, Department of Business Administration. These students were recruited from various degrees of classes with the permission of instructors.

A questionnaire was prepared for the assessment of locus of control and job selection decisions. The students were surveyed their attitudes and perceptions about their locus of control orientations and the motivators that effect their potential job selection decisions.

A sample of 200 undergraduate students voluntarily completed the questionnaire in total. Data was gained as distributing survey in hand. Questionnaires obtained from 13 students were eliminated owing to inconsistent data. Data obtained from those 187 questionnaires were analyzed through the Microsoft Excel and ReCal web based program.

The questionnaire was composed of 72 items in two scales (locus of control and job selection decisions). Apart from items in two scales, data of age and gender of respondent were collected but not used because to be out of propose of study.

\subsection{Scale and Analysis}

First of all, it was planned to measure perceived locus of control using the well-known instrument developed by Rotter. It is known as the "I-E scale". One point is given for each 
external response to a question. The higher score on the instrument, the more external the subject (Miller et al. 1982). Rotter's scale was adapted to Turkish by Dağ (1991). Dağ had developed locus of control scale, other than Rotter's, for Turkish samples in 2002 (Dağ, 2002). Dağ's scale is a Likert type interval scale consists of 5 factors and 47 items in total. Dağ's scale was used in this study (Dağ, 2002).

The job selection decisions were measured by the 25-item scale of Aycan and Fikret-Pasa (2003). This scale is an adaptation of the 48-item work rewards scale that was developed by Kanungo and Hartwick (1987). Aycan and Fikret-Pasa identified those items as the "motivators assessing the extent to which participants considered each as important in selecting a job or an employment setting" (Aycan and Fikret Paşa 2003). Aycan and Fikret-Paşa's scale was converted to 5-point likert importance scale (Very Important, Important, Neither Important nor Unimportant, Unimportant, Very Unimportant) for analysis instead of Q-sort technique that was used by Aycan and Fikret-Pasa (2003).

Locus of control and job selection decisions scales were measured reliability using data collected in this study. In order to measure internal consistency (reliability) it was used Cronbach's Alpha statistics. The results of reliability analysis for two scales are shown in Table 2.

Table 2. Cronbach's Alpha Values of Scales

\begin{tabular}{|c|c|c|}
\hline Scales & Cronbach's Alpha & Number of Items \\
\hline Job Selection Decisions & 0.899 & 25 \\
\hline Locus of Control & 0.864 & 47 \\
\hline
\end{tabular}

Cronbach's Alpha value of job selection decisions scale is 0.899. Cronbach's Alpha value of locus of control scale is 0.864 . Both scales of Cronbach's Alpha values are adequate for analysis. These results indicate the reliability of scales used in this survey. Reliability of factors of locus of control scale were measured. First factor is personal control. It contains 18 items. Reliability result is shown in Table 3. Reliability value of personal control is 0.835 . This result is adequate for analysis. None of items were extracted.

Table 3. Cronbach's Alpha Values of Factor 1 of the locus of control: Personal Control

\begin{tabular}{|c|c|}
\hline Cronbach's Alpha & Number of Items \\
\hline 0.835 & 18 \\
\hline
\end{tabular}

Second factor is belief in chance. It contains 11 items. Reliability result is shown in Table 4. But one item was extracted in reliability analysis. Reliability value of belief in chance is 0.669 . This result is adequate for analysis.

Table 4. Cronbach's Alpha Values of Factor 2 of the locus of control: Belief in Chance

\begin{tabular}{|c|c|}
\hline Cronbach's Alpha & Number of Items \\
\hline 0.669 & 10 \\
\hline
\end{tabular}




\section{1) Macrothink}

Business and Economic Research

ISSN 2162-4860

2017, Vol. 7, No. 1

Third factor is Meaninglessness of the Effortfulness. It contains 10 items. Reliability result is shown in Table 5. Reliability value of belief in chance is 0.826 . None of items were extracted. This result is adequate for analysis.

Table 5. Cronbach's Alpha Values of Factor 3 of the locus of control: Meaninglessness of the Effortfulness

\begin{tabular}{|c|c|}
\hline Cronbach's Alpha & Number of Items \\
\hline 0.826 & 10 \\
\hline
\end{tabular}

Forth factor is Belief in Fate. It contains 3 items. Reliability result is shown in Table 6. Reliability value of belief in chance is 0.654 . None of items were extracted. This result is adequate for analysis.

Table 6. Cronbach's Alpha Values of Factor 4 of the locus of control: Belief in Fate

\begin{tabular}{|c|c|}
\hline Cronbach's Alpha & Number of Items \\
\hline 0.654 & 3 \\
\hline
\end{tabular}

Fifth factor is Belief in an Unjust World. It contains 5 items. Reliability result is shown in Table 7. Reliability value of belief in chance is 0.664 . None of items were extracted. This result is adequate for analysis.

Table 7. Cronbach's Alpha Values of Factor 5 of the locus of control: Belief in an Unjust World

\begin{tabular}{|c|c|}
\hline Cronbach's Alpha & Number of Items \\
\hline 0.664 & 5 \\
\hline
\end{tabular}

Locus of control scale result was separated two main groups as external and internal. If mean of locus of control score of person is above three, person is labeled external, if not, labeled internal. Thus, respondents were labelled with respect to locus of control for agreement analysis. According to results 24 percent of respondents (44 students) have external locus of control, 76 percent of respondents (143 students) have internal locus of control. For example, computing of one of the respondents for locus of control (One item was extracted because of factor 2) is,

$$
\frac{4+4+5+\cdots+1+3+2}{46}=2.8
$$

According to this result, the respondent was labeled as internal locus of control. This computing applied for other respondents too.

Internal and external locus of control were determined as rater and computed agreement with respect to job selection decisions in this study. Inter-rater agreement was calculated for internal locus of control and external locus of control about job selection decisions. Furthermore, internal and external discrimination was applied for factors of locus of control 
using same agreement computing as above. Thus, coefficients of agreement were computed for six different assessments which were main locus of control, personal control, belief in chance, meaninglessness of the effortfulness, belief in fate, belief in an unjust world. It was used three coefficient of agreement for each assessment.

Raters, have internal and external locus of control, rated with respect to job selection decisions. Rating was applied two different forms. First was used mean value of results of respondents had internal or external locus of control for each job selection item individually. Second was used mod value of results of respondents had internal or external locus of control for each job selection item individually. So, agreement was computed for mod values by using Cohen's kappa and percent agreement and for mean values by using Krippendorff's Alpha. ReCal, web based utility, was used for computing agreement. ( http://dfreelon.org/utils/recalfront/)

Agreement of internal and external locus of control was computed by using mod values. Percent agreement of locus of control types about the motivators of job selection decision is computed as 0.84 . Cohen's Kappa coefficient of locus of control types about the motivators of job selection decision is computed as 0.432 . It was computed also by using mean values. Krippendorff's Alpha coefficient of locus of control types about the motivators of job selection decision is computed as 0.467 . Results are shown totally in Table 8 and Figure 1.

Table 8. Agreement results of locus of control types with respect to motivators of job selection decisions

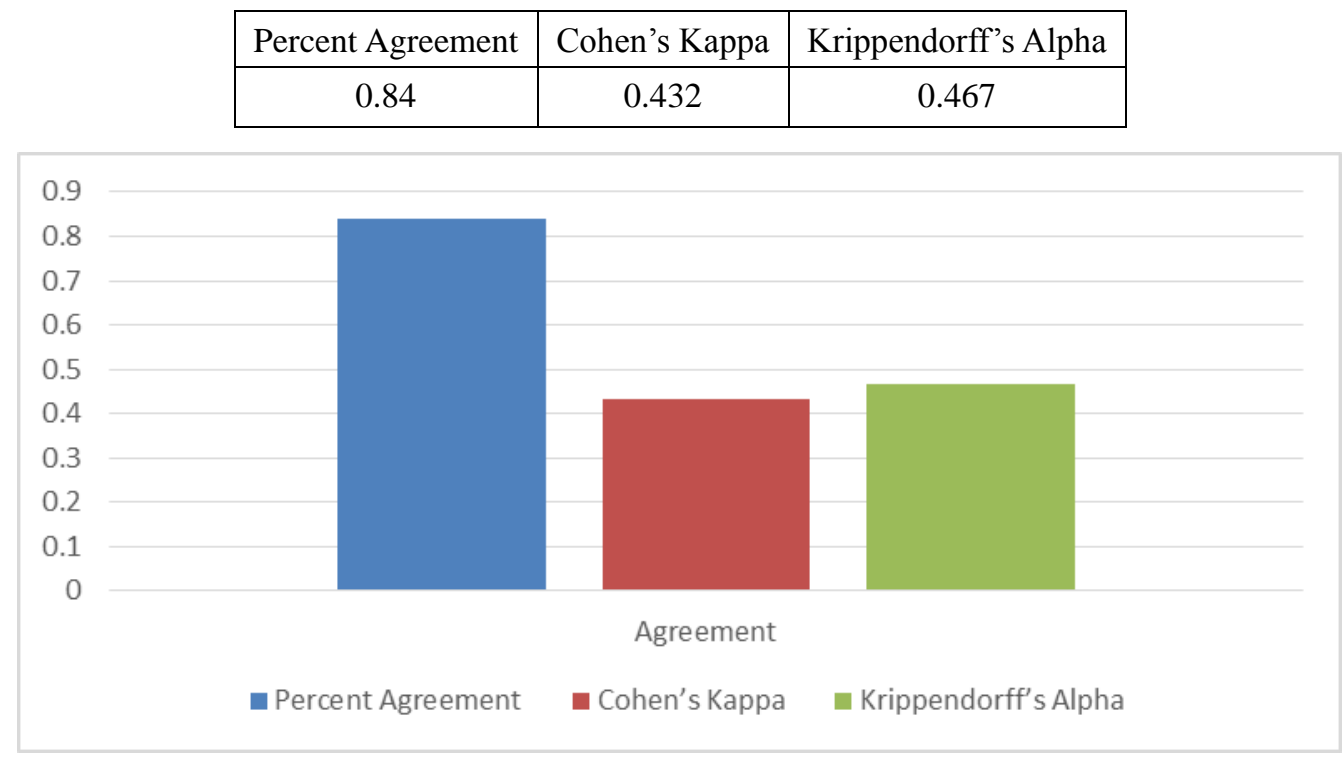

Figure 1. Agreement results of locus of control types with respect to motivators of job selection decisions

Each factors of locus of control were split due to below three and upper threescore of factor.

Respondents were split two groups as low and high personal control score with respect to factor 1. Agreement between two groups was computed by using mod values. Percent agreement between as low and high personal control about the motivators of job selection 
decision is computed as 0.72. Cohen's Kappa coefficient is computed as 0.342 . Krippendorff's Alpha is computed as -0.087 by using mean values. Results are shown totally in Table 9. Krippendorff's Alpha coefficient less than zero indicates disagreements.

Table 9. Agreement results of between low and high personal control with respect to motivators of job selection decisions

\begin{tabular}{|c|c|c|}
\hline Percent Agreement & Cohen's Kappa & Krippendorff's Alpha \\
\hline 0.72 & 0.342 & -0.087 \\
\hline
\end{tabular}

Respondents were split into two groups as low and high belief in chance score with respect to factor 2. Agreement between two groups was computed by using mod values. Percent agreement between as low and high belief in chanceabout the motivators of job selection decision is computed as 0.76. Cohen's Kappa coefficient is computed as 0.348 . Krippendorff's Alpha is computed as 0.735 by using mean values. Results are shown totally in Table 10.

Table 10. Agreement results of between low and high belief in chancewith respect to motivators of job selection decisions

\begin{tabular}{|c|c|c|}
\hline Percent Agreement & Cohen's Kappa & Krippendorff's Alpha \\
\hline 0.76 & 0.348 & 0.735 \\
\hline
\end{tabular}

Respondents were split into two groups as low and high meaninglessness of the effortfulness scorewith respect to factor 3. Agreement between two groups was computed by using mod values. Percent agreement between as low and high meaninglessness of the effortfulness about the motivators of job selection decision is computed as 0.64. Cohen's Kappa coefficient is computed as 0.059 . Krippendorff's Alpha is computed as 0.471 by using mean values. Results are shown totally in Table 11.

Table 11. Agreement results of between low and high meaninglessness of the effortfulness with respect to motivators of job selection decisions

\begin{tabular}{|c|c|c|}
\hline Percent Agreement & Cohen's Kappa & Krippendorff's Alpha \\
\hline 0.64 & 0.059 & 0.471 \\
\hline
\end{tabular}

Respondents were split into two groups as low and high belief in fate score with respect to factor 4. Agreement between two groups was computed by using mod values. Percent agreement between as low and high belief in fateabout the motivators of job selection decision is computed as 0.76. Cohen's Kappa coefficient is computed as 0.312 . Krippendorff's Alpha is computed as 0.531 by using mean values. Results are shown totally in Table 12.

Table 12. Agreement results of between low and high belief in fatewith respect to motivators of job selection decisions

\begin{tabular}{|c|c|c|}
\hline Percent Agreement & Cohen's Kappa & Krippendorff's Alpha \\
\hline 0.76 & 0.312 & 0.531 \\
\hline
\end{tabular}


Respondents were split into two groups as low and high belief in an unjust world scorewith respect to factor 5. Agreement between two groups was computed by using mod values. Percent agreement between as low and high belief in an unjust worldabout the motivators of job selection decision is computed as 0.76. Cohen's Kappa coefficient is computed as 0.312 . Krippendorff's Alpha is computed as -0.087 by using mean values. Results are shown totally in Table 13. Krippendorff's Alpha coefficient less than zero indicates disagreements.

Table 13. Agreement results of between low and high belief in an unjust world with respect to motivators of job selection decisions

\begin{tabular}{|c|c|c|}
\hline Percent Agreement & Cohen's Kappa & Krippendorff's Alpha \\
\hline 0.76 & 0.312 & 0.265 \\
\hline
\end{tabular}

\section{Findings}

First of all, percent agreement is higher than sixty percent at six different assessments. According to Cohen's kappa, the highest agreement is between locus of control types (0.432) it indicates moderate agreement, lowest is between low and high meaninglessness of the effortfulness. (0.059). According to Krippendorff's Alpha, the highest agreement is between low and high belief in chance (0.735) it indicates substantial agreement, lowest is between low and high personal control in fact there is disagreement.

Agreement of locus of control types about motivators of job selection decisions is adequate with respect to three measures. Agreement of between low and high belief in chance score about motivators of job selection decisions is generally high with respect to three measures.

According to results, Krippendorff's alpha has maximum range (0.822) and maximum standard deviation (0.28). Percent Agreement has maximum mean and minimum standard deviation. Comparing of coefficient of agreement with respect to standard deviation, range and mean are shown in Table 14.

Table 14. Comparing of coefficients of agreement

\begin{tabular}{|c|c|c|c|}
\hline & Percent Agreement & Cohen's Kappa & Krippendorff's Alpha \\
\hline Standard Deviation & 0.065 & 0.126 & 0.281 \\
\hline Range & 0.200 & 0.373 & 0.822 \\
\hline Mean & 0.747 & 0.301 & 0.397 \\
\hline
\end{tabular}

Kappa and alpha gave opposite agreement results about personal control and meaninglessness of the effortfulness. While kappa is 0.059 , alpha is 0.471 and while kappa is 0.342 , alpha is -0.087 . There is a discrepancy in these assessments.

\section{Conclusions and Recommendations}

This study aimed to compare agreement coefficients by measuring agreements between locus of control types with respect to job selection decision. Raters for agreement are identified by using mean of locus of control items as internal and external. In other words, respondents are split have internal locus of control and have external locus of control. Thus it is aimed measuring agreement with respect to job selection decision. 
Both mean and mod values were used for rating. By this way, Cohen's kappa (for nominal) and Krippendorff's Alpha (ratio) were used for measuring agreement. These coefficients of agreement were compared. It was seemed that Krippendorff's alpha has maximum standard deviation and range. Cohen's kappa was more stable than alpha. It was seemed that using mean or mod could be revealed discrepancy about agreement.

As apart from earlier studies, it was compared three coefficients of agreement about job selection decisions according to locus of control in this study.

Results indicated that there was an agreement between internals and externals at a different level. However, it is seemed generally low agreement.

For further research, different coefficient of agreement can use to measure agreement. Agreement of each of motivators of job selection decisions can investigate by using different discrimination.

\section{References}

Ahn, T. (2015). Locus of Control and Job Turnover. Economic Inquiry, 53(2), 1350-1365. https://doi.org/10.1111/ecin.12173

Akkaya, R., \& Akyol, B. (2016). The Relationship between Teachers' Locus of Control and Job Satisfaction: A Mixed Method Study. International Online Journal of Educational Sciences, 8(3), 71-82. https://doi.org/10.15345/iojes.2016.03.008

Araujo, J., \& Born, D. G. (1985). Calculating Percentage Agreement Correctly But Writing Its Formula Incorrectly. Behavior Analyst, 8(2), 207-208.

Ato, M., López, J. J., \& Benavente, A. (2011). A Simulation Study of Rater Agreement Measures with 2x2 Contingency Tables. Psicológica, 32, 385-402.

Aycan, Z., \& Fikret-Pasa, S. (2003). Career Choices, Job Selection Criteria, and Leadership Preferences in a Transitional Nation: The Case of Turkey. Journal of Career Development, 30(2), 129-144. https://doi.org/10.1177/089484530303000203

Bacanli, F. (2012). Kariyer Karar Verme Güçlükleri ve Meslek Seçimine İlişkin Akılcı Olmayan İnançların İlişkisi. Türk Psikolojik Danışma ve Rehberlik Dergisi, 4(37), 86-95. http://dergipark.ulakbim.gov.tr/tpdrd/article/view/1058000144/1058000146

Banerjee, M., et al. (1999). Beyond kappa: A Review Of Interrater Agreement Measures. The Canadian Journal of Statistics, 27(1), 3-23. https://doi.org/10.2307/3315487

Bretz, R. D., Jr., \& Judge, T. A. (1992). The Role of Human Resource Systems in Job Choice Decisions (CAHRS Working Paper \#92-30). Ithaca, NY: Cornell University, School of Industrial and Labor Relations, Center for Advanced Human Resource Studies. http://digitalcommons.ilr.cornell.edu/cgi/viewcontent.cgi?article=1315\&context=cahrswp

Caliendo, M. et al (2015). Locus of Control and Job Search Strategies. The Review of Economics and Statistics, 97(1), 88-103. 


\section{Al Macrothink}

Business and Economic Research ISSN 2162-4860 2017, Vol. 7, No. 1

Chan, S. Y., \& Ho, Simon, S. M. (2000). Desired Attributes of Public Accounting Firms in The Job Selection Process: An Empirical Examination of Accounting Graduates' Perceptions. Accounting Education, 9(4), 315-327. https://doi.org/10.1080/09639280010010452

Cohen, J. (1960). A Coefficient of Agreement for Nominal Scales. Educational and Psychological Measurement, 20(1), 37-46.

Corrigall, E. A. (2008). Welfare States, Families, Job Attribute Preferences And Work. Cross Cultural Management, 15(2), 144-161. https://doi.org/10.1108/13527600810870598

Dağ, İ. (1991). Rotter'in İç-Dış Kontrol Odağı Ölçeği (Ridkoö)'nin Üniversite Öğrencileri İçin Güvenirliği ve Geçerliği. Psikoloji Dergisi, 7(26), 10-16.

http://www.ihsandag.gen.tr/index_dosyalar/Dag1991Rotter.pdf

Freelon, D. G. (2010). ReCal: Intercoder Reliability Calculation as a Web Service. International Journal of Internet Science, 5(1), 20-33.

http://www.ijis.net/ijis5_1/ijis5_1_freelon.pdf

Gangai, K. N. et al (2016). Association between Locus of Control and Job Satisfaction in Employees: A Critical Review. The International Journal of Indian Psychology, 3(2), 55-68. http://oaji.net/articles/2016/1170-1459010864.pdf

Gwet, K. L. (2016). Testing the Difference of Correlated Agreement Coefficients for Statistical Significance. Educational and Psychological Measurement, 76(4), 609-637. http://www.agreestat.com/research_papers/correlated_agreement_coefficients_educational_a nd_psychological_measurement_2016.pdf

Hallgren, K. A. (2012). Computing Inter-Rater Reliability for Observational Data: An Overview and Tutorial. Tutor Quant Methods Psychol, 8(1), 23-34. https://www.ncbi.nlm.nih.gov/pmc/articles/PMC3402032/pdf/nihms372951.pdf

Hareli, S., Klang M., \& Hess U. (2008). The Role of Career History in Gender Based Biases in Job Selection Decisions. Career Development International, 13(3), 252-269. https://doi.org/10.1108/13620430810870502

Hayes, A., \& Krippendorff F. K. (2007). Answering the Call for a Standard Reliability Measure for Coding Data. Communication Methods And Measures. 1 (1). 77-89. https://doi.org/10.1080/19312450709336664

Hooft, E. A. J. van \& Crossley, C. D. (2008). The Joint Role of Locus of Control and Perceived Financial Need in Job Search. International Journal of Selection and Assessment, 16(3), 258-271. https://doi.org/10.1111/j.1468-2389.2008.00432.x

Kanungo, R. N., \& Hartwick, J. (1987). An Alternative to the Intrinsic-Extrinsic Dichotomy of Work Rewards. Journal of Management, 13(4), 751-766.

https://search.proquest.com/docview/215260264? accountid=12251

Keller L. R., Simon, Jay, \& Wang, Y. (2009). Multiple-Objective Decision Analysis Involving Multiple Stakeholders. Tutorials in Operations Research, 139-155. 
https://doi.org/10.1287/educ.1090.0066

Kirilenko, A. P., \& Stepchenkova S. (2016). Inter-Coder Agreement in One-to-Many Classification: Fuzzy Kappa. PLoS ONE, 11(3), 1-14.

https://doi.org/10.1371/journal.pone.0149787

Krippendorff, K. (2004 a). Reliability in Content Analysis: Some Common Misconceptions and Recommendations. Human Communication Research, 30(3), 411-433.

https://doi.org/10.1111/j.1468-2958.2004.tb00738.x

Krippendorff, K. (2004 b). Measuring the Reliability of Qualitative Text Analysis Data. Quality and Quantity, 38(6), 787-800. https://doi.org/10.1007/s11135-004-8107-7

Krippendorff, K. (2011 a). Agreement and Information in the Reliability of Coding. Communication Methods and Measures, 5(2), 93-112.

https://doi.org/10.1080/19312458.2011.568376

Krippendorff, K. (2011 b). Computing Krippendorff's Alpha-Reliability. Retrieved from http://repository.upenn.edu/asc_papers/43

Kulkarni, M., \& Nithyanand S. (2012). Social Influence and Job Choice Decisions. Employee Relations, 35(2), 139-156. https://doi.org/10.1108/01425451311287844

Lombard, M., Snyder-Duch, J. R., \& Bracken, C. C. (2002). Content Analysis in Mass Communication Assessment and Reporting Of Intercoder Reliability. Human Communication Research, 28(4), 587-604. https://doi.org/10.1111/j.1468-2958.2002.tb00826.x

McGee, A. D. (2015). How the Perception of Control Influences Unemployed Job Search. ILR Review, 68(1), 184-211. https://doi.org/10.1177/0019793914556245

Miller, D. et al. (1982). Top Executive Locus Of Control And Its Relationship To Strategy-Making, Structure, And Environment. Academy of Management Journal, 25(2), 237-253.

Mustapha, M., \& Hassan, M. H. A. (2012). Accounting Students' Perception on Pursuing Professional Examination. International Journal of Education, 4(4), 1-15.

https://doi.org/10.5296/ije.v4i4.1546

Öztemel, K. (2012). Kariyer Kararsızlığı ile Mesleki Karar Verme Öz Yetkinlik ve Kontrol Odağı Arasındaki İlişkiler. GEFAD / GUJGEF, 32(2), 459-477.

http://gefad.gazi.edu.tr/article/view/5000078420

Rotter, J. B. (1990). Internal Versus External Control of Reinforcement A Case History of a Variable. American Psychologist, 45(4), 489-193.

https://doi.org/10.1037/0003-066X.45.4.489

Şahin, M. et al. (2015). Mesleki Kararsızlığın Yordanmasında Kontrol Odağı ve Mantık Dış1 İnançların Rolü. Türk Psikolojik Danışma ve Rehberlik Dergisi, 5(43), 11-20.

Scott, W. A. (1955). Reliability of Content Analysis: The Case of Nominal Scale Coding. The 
Public Opinion Quarterly, 19(3), 321-325. http://www.jstor.org/stable/2746450

Silvester, J. et al. (2002). Locus of Control, Attributions and Impression Management In The Selection Interview. Journal of Occupational and Organizational Psychology, 75, 59-76. https://doi.org/10.1348/096317902167649

Taylor, J., \& Watkinson, D. (2007). Indexing Reliability for Condition Survey Data. The Conservator, 30, 49-62. https://doi.org/10.1080/01410096.2007.9995223

Warrens, M. J. (2013). A Comparison of Cohen's Kappa and Agreement Coefficients by Corrado Gini. IJRRAS, 16(3), 345-351.

http://www.arpapress.com/Volumes/Vol16Issue3/IJRRAS_16_3_03.pdf

\section{Glossary}

ReCal: Reliability Calculator

\section{Copyright Disclaimer}

Copyright for this article is retained by the author(s), with first publication rights granted to the journal.

This is an open-access article distributed under the terms and conditions of the Creative Commons Attribution license (http://creativecommons.org/licenses/by/3.0/). 